\title{
Good clinical response to alectinib, a second generation ALK inhibitor, in refractory neuroblastoma
}

Heath $\mathrm{JA}^{1}$, Campbell MA ${ }^{2}$, Thomas $\mathrm{A}^{1}$ and Solomon $\mathrm{B}^{3}$

${ }^{1}$ Royal Hobart Hospital, Hobart, Australia

${ }^{2}$ Royal Children's Hospital, Melbourne, Australia

${ }^{3}$ Peter MacCallum Cancer Institute, Melbourne, Australia

<john.heath@ths.tas.gov.au>

Abbreviations:

ALK

EKG

MIBG

NSCLC anaplastic lymphoma kinase

electrocardiogram

metaiodobenzylguanine

non small cell lung cancer

This is the author manuscript accepted for publication and has undergone full peer review but has not been through the copyediting, typesetting, pagination and proofreading process, which may lead to differences between this version and the Version of Record. Please cite this article as doi: $10.1002 /$ pbc. 27055 . 


\section{To The Editors,}

We wish to report first use of alectinib (Alecensa; Roche Ltd), a second generation anaplastic lymphoma kinase $(A L K)$ inhibitor, in a case of heavily pre-treated, refractory, metastatic neuroblastoma. Patients with refractory and or relapsed neuroblastoma have a poor outcome with conventional multimodality therapy. Activating mutations in the tyrosine kinase domain encoding regions of $A L K$ have been identified as the most common cause of familial neuroblastoma and account for $10-15 \%$ of sporadic neuroblastoma cases [1]. Experience with the first-in-class ALK inhibitor crizotinib in children with refractory neuroblastoma has shown encouraging results. Crizotinib monotherapy achieved stable disease, with median progression free survival of over 12 months [2]. Alectinib is a second generation ALK tyrosine kinase inhibitor with greater potency against wildtype and mutant $A L K$ and improved CNS penetration compared with crizotinib. A recent phase 3 study demonstrated the superiority of alectinib over crizotinib in ALK rearranged non small cell lung cancer (NSCLC) [3]. To our knowledge, the activity of alectinib in neuroblastoma has not been described.

Our patient, a 15-year-old female was diagnosed with stage III neuroblastoma without amplified MYCN. Initial disease sites included a left adrenal mass and regional lymph nodes. She achieved a complete remission after receiving treatment according to a standard high risk-neuroblastoma protocol. The patient remained disease free for 11 months, after which she relapsed with multiple nodal masses throughout the posterior mediastinum. Next generation sequencing of the relapsed tumor confirmed an ALK mutation at exon 24 F1245C. Treatment of the relapse included conventional salvage chemotherapy, surgical resection and external beam radiation. Persistent MIBG avid disease was treated with ceritinib monotherapy. A partial response was achieved and sustained for 12 months, before multiple new sites of disease (lung, supraclavicular nodes bilaterally) were detected. A repeat biopsy of supraclavicular nodes confirmed persistence of the known ALK mutation. Radionuclide therapy (MIBG and lutetium), together with external beam radiation 
therapy resulted in temporary improvements before further disease progression within pleural and lung nodules occurred..

Because there is evidence for resistance to ceritinib with NSCLC cases harbouring the F1245C ALK mutation [5], treatment with an alternative second generation $A L K$ inhibitor was offered. Alectinib therapy is generally well-tolerated and most common adverse events observed, which include fatigue, myalgias, peripheral edema and constipation, are minor [5]. Alectinib monotherapy was started after informed consent, with monitoring of blood counts, liver, and kidney function, muscle enzymes and cardiac function by EKG. Apart from some mild nausea, our patient tolerated the drug. There were no clinical or metabolic adverse effect at a dose of 600mg QID over 4 months. She improved symptomatically (severe pain requiring opiate analgesia resolved) and evaluation after 8 weeks revealed a very good partial response (Figure 1). She remained stable for a total of 16 weeks, at which time she presented with a new onset visible, right sided chest wall mass, contiguous with a known, pleurally based tumor. As with other tyrosine kinase inhibitors, use of alectinib as monotherapy leads to the emergence of resistance. Genetic analysis suggests that mutations within ALK kinase domain or up-regulation of an alternative signaling pathway are the likely mechanisms of resistance $[6,7]$.

In summary, we observed a partial response with alectinib in a patient with chemotherapy-resistant $A L K$ mutation positive metastatic neuroblastoma. We are unable to say in this case if the targeted mutation was present in the original tumor or developed at relapse. The excellent oral bioavailability and safety profile of the agent makes it ideal for use in heavily pretreated patients, although monotherapy is known to lead to resistance and undoubtedly short response times. Encouraging results in refractory tumors suggests there may be a role for its use in combination with other agents as frontline therapy for high-risk neuroblastoma.

\section{Financial support and sponsorship}

Nil.

\section{Conflicts of interest}

Dr Solomon serves as a medical consultant to Pfizer and Roche 


\section{References}

1. Carpenter EL, Mossé YP. Targeting ALK in neuroblastoma - preclinical and clinical advancements. Nat Rev Clin Oncol. 2012;9:391

2. Mossé YP, Lim MS, Voss SD, Wilner K, Ruffner K, Laliberte J, et al. Safety and activity of crizotinib for paediatric patients with refractory solid tumours or anaplastic large-cell lymphoma: A Children's Oncology Group phase 1 consortium study. Lancet Oncol. 2013;14:472-80.

3. Peters S, Camidge DR, Shaw AT, Gadgeel S, Ahn JS, Kim DW, et al. Alectinib versus crizotinib in untreated ALK-positive non-small-cell lung cancer. NEJM 2017; 377: 829-38.

4. Kodityal S, Elvin JA, Squillace R, Aqarwal N, Miller VA, Ali SM, et al. A novel acquired ALK F1245C mutation confers resistance to crizotinib in ALKpositive NSLC but is sensitive to ceritinib. Lung Cancer 2016; 92: 19-21.

5. Gadgeel SM, Gandhi L, Riely GJ, Chiappori AA, West HL, Azada MC, et al. Safety and efficacy of alectinib against systemic disease and brain metastatses in patients with crizotinib-resistant ALK-rearranged non-small-cell lung cancer (AF-002JG): results from the dose-finding portion of a phase $1 / 2$ study. Lancer Oncol 2014; 15: 1119-28.

6. Katayama R, Friboulet L, Koike S, Lockerman EL, Khan TM, Gainor JF, et al. Two novel ALK mutations mediate acquired resistance to the next-generation ALK inhibitor alectinib. Clin Cancer Res 2014; 20: 5686-96.

7. Yoshida R, Sasaki $T$, Minami $Y$, Hibino $Y$, Okumura $S$, Dado $M$, et al. Activation of Src signalling mediates acquired resistance to ALK inhibition in lung cancer. Int J Oncol 2017; 51: 1533-40. 
Figure 1 Comparative computerized tomography (CT) scans (A) pre-alectinib and (B) after three months treatment with alectinib monotherapy showing reduction in size of pleurally based metastatic neuroblastoma

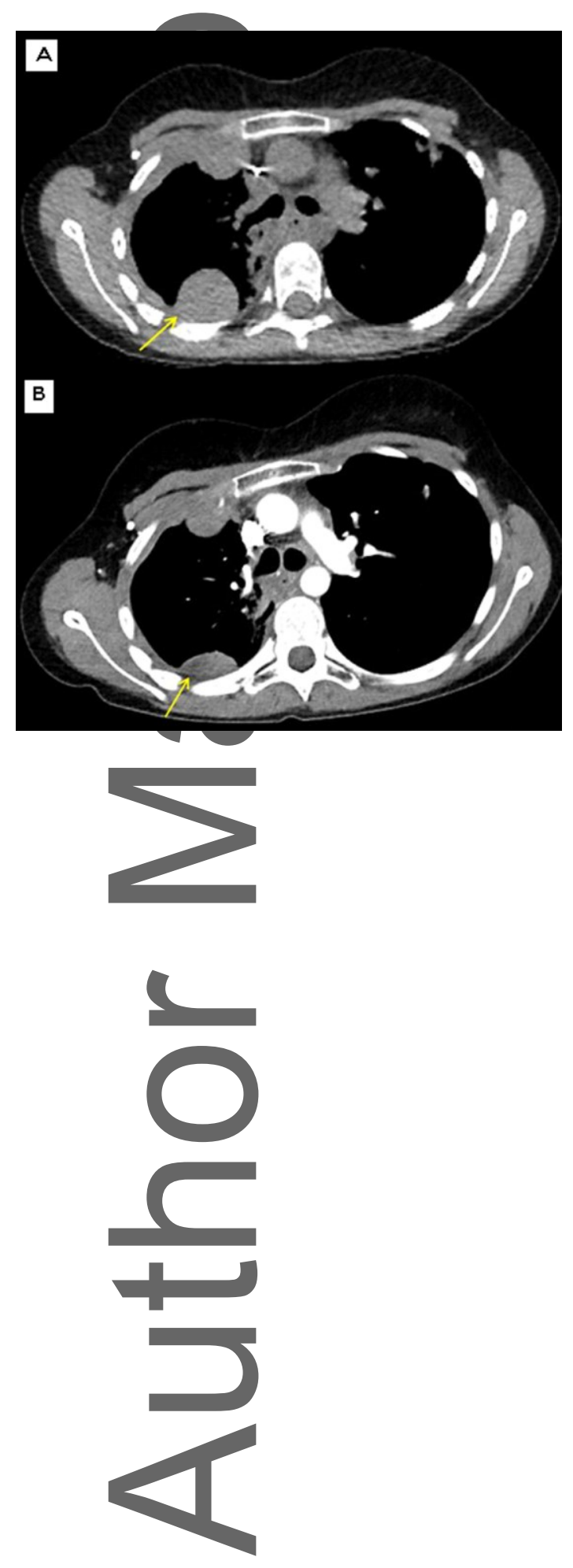

This article is protected by copyright. All rights reserved. 


\section{University Library}

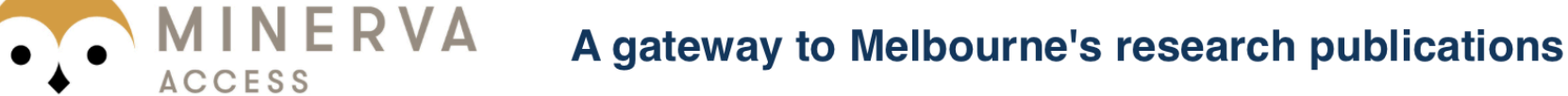

Minerva Access is the Institutional Repository of The University of Melbourne

Author/s:

Heath, JA;Campbell, MA;Thomas, A;Solomon, B

Title:

Good clinical response to alectinib, a second generation ALK inhibitor, in refractory neuroblastoma

Date:

2018-07-01

Citation:

Heath, J. A., Campbell, M. A., Thomas, A. \& Solomon, B. (2018). Good clinical response to alectinib, a second generation ALK inhibitor, in refractory neuroblastoma. PEDIATRIC BLOOD \& CANCER, 65 (7), https://doi.org/10.1002/pbc.27055.

Persistent Link:

http://hdl.handle.net/11343/283793 